Niepełnosprawność. Dyskursy pedagogiki specjalnej

Nr 33/2019

Disability. Discourses of special education

No. 33/2019

\title{
Zdzisława Janiszewska-Nieścioruk
}

Uniwersytet Zielonogórski

\section{O ciągle nierozwiązanych problemach ogólnodostępnej edukacji utrudniających proces inkluzji uczniów/osób z niepełnosprawnością}

W treści artykułu wskazano na te słabości czy utrudnienia w przestrzeni ogólnodostępnej edukacji, które proces społecznej inkluzji osób z niepełnosprawnościami czynią ciągle problematycznym. Kwestie, na których się skupiono, to przede wszystkim brak działań na rzecz budowania kapitału społecznego w szkole, jako niezbędnej bazy do praktykowania w niej wzajemnej, opartej na zaufaniu i szacunku współpracy, otwartej na możliwość włączania w nią rodzin uczniów i lokalnej wspólnoty. Za równie istotny i dlatego domagający się szybkich rozwiązań uznano problem ubóstwa, które zbyt często jest powodem wykluczania i marginalizowania uczniów nim dotkniętych przez pełnosprawnych rówieśników i szkolny personel. To podwójne wykluczenie dzieci z rodzin ubogich obliguje wszystkie angażujące się w ich edukację i wspieranie podmioty do działań zorientowanych na kompensację przez szkołę socjalizacyjnej funkcji rodziny. W tekście podjęto także, zbyt rzadko w kontekście inkluzji edukacyjnej analizowany wątek, jakim jest nuda w szkole i jej destrukcyjny wpływ na uczniów i proces ich włączania.

Słowa kluczowe: edukacja inkluzyjna, uczeń/osoba z niepełnosprawnością, uczeń/osoba o specjalnych potrzebach, kapitał społeczny, ubóstwo, nuda w szkole

\section{On the still unresolved problems of public education obstructing the process of inclusion of students/people with disabilities}

The article presents weaknesses and difficulties in the area of public education, in which the process of social inclusion of people with disabilities is still problematic. The main focus of this paper is the lack of measures needed to build the school's social capital, which remains a necessary base to practice simultaneously, based on the cooperation of both trust and respect, open to the possibility of including the pupils' families and the local community. The issue of poverty, which often becomes the reason of exclusion and marginalisation of students by their non-disabled peers and school staff, is equally important. This double exclusion of children from poor families obliges all entities involved in their education and support to actions aimed the school's compensation, through the socializing function of a family. The article also delineates a very rarely analyzed, in the context of educational inclusion, thread of boredom at school and its destructive impact on pupils and the process of their inclusion.

Keywords: inclusive education, students/people with disabilities, students/people with special needs, social capital, poverty, boredom at school 


\section{Wprowadzenie}

Obecnie wprowadzane w naszym kraju kolejne regulacje prawne i działania, mające na celu ograniczanie społeczno-ekonomicznych i edukacyjnych problemów osób z niepełnosprawnościami, nie gwarantują - niestety - oczekiwanej skuteczności ich inkluzji czy integracji, ale bez wątpienia mogą być dobrym punktem wyjścia do bardziej niż dotąd niezawodnej jej realizacji. Dlatego ciągle za priorytetową wypada uznać konieczność i zarazem potrzebę kreowania w Polsce ogólnego, dobrego klimatu polityczno-społecznego dla poszukiwania satysfakcjonujących te osoby, projakościowych i dlatego zróżnicowanych w swej programowo-organizacyjnej ofercie, inkluzyjnych rozwiązań. W tym miejscu wypada przypomnieć, że w naszej rodzimej przestrzeni, (w przeciwieństwie do krajów skandynawskich, gdzie ruch na rzecz integracji zainicjowali politycy), począwszy od lat 60., a nawet jeszcze w latach 90. ub. wieku, dyskusję na ten temat prowadziły najczęściej środowiska zajmujące się profesjonalnie osobami z niepełnosprawnością, z różną skutecznością włączając w nią inne grupy społeczne. Ponadto, funkcjonujące ówcześnie regulacje prawne odnoszące się do sfery edukacji osób z niepełnosprawnością, ich wsparcia, opieki, zatrudnienia itp. cechowała niespójność, której powodem był brak międzyresortowej koordynacji uzgodnień legislacyjnych i brak jednolitej polityki państwa. W miarę spójne i sprzyjające integracji prawo zaczęto tworzyć dopiero w późnych latach 90. ub. wieku, m.in. dozwalając na uruchamianie integracyjnych form w systemie ogólnodostępnej edukacji. Nadal jednak, co z ubolewaniem należy skonstatować, zaangażowanie elit politycznych, niezależnie od reprezentowanej opcji czy lansowanych poglądów, $\mathrm{w}$ problemy szeroko rozumianej rehabilitacji i wspierania społecznej inkluzji dzieci, młodzieży i dorosłych osób z niepełnosprawnością, jak też ich wpływ na kształtowanie opinii publicznej w tej kwestii, jest raczej niezadowalający. Ciągle odczuwa się brak szeroko zakrojonej publicznej debaty na temat tych zagrożeń, barier czy słabości, które nadal tkwią w otoczeniu cywilizacyjnym, w środowisku społecznym, w sferze kulturowych wartości i sposobów zachowania się ludzi, a w szczególności w systemie ogólnodostępnej edukacji i mogą stanowić poważną przeszkodę do spontanicznego tworzenia projektów i programów społecznego współdziałania oraz pomyślnych prognoz na integracyjne funkcjonowanie społeczeństwa dla wszystkich [por. Janiszewska-Nieścioruk, Grzegorzewska, Herberger i in., 2015; Sadowska 2005]. Podejmując próbę włączenia się w taką debatę, za przedmiot mojej szczególnej refleksji przyjęłam te problemy czy słabości, które jako ciągle obecne w edukacyjnej przestrzeni czynią ją zbyt często nieinkluzyjną dla wielu dzieci/uczniów z niepełnosprawnościami i ich rodziców/opiekunów. 
Włączanie staje się problematyczne przede wszystkim w sytuacji braku działań na rzecz tworzenia kapitału społecznego w szkole i wreszcie uczynienia z niej (samo)uczącej się organizacji. Za kolejną, domagającą się równie szybkich rozwiązań kwestię uznaję ubóstwo, które przy braku czy niedostatkach spersonalizowanego wsparcia jest szczególnie dotkliwie doświadczane przez uczniów z niepełnosprawnościami i o szczególnych potrzebach, nierzadko z tego powodu naznaczanych i wyłączanych z klasy/grupy przez pełnosprawnych rówieśników i szkolny personel. Dostrzegam także problem związany z realizacją zadań programowych na kolejnych etapach edukacyjnych, ale nie będę odnosić się do najczęściej dyskutowanego nadmiarowego obciążenia uczniów zbędnymi treściami czy źle ustawionych priorytetów w sposobie aktualnie realizowanego kształcenia, lecz podejmę zbyt rzadko w kontekście inkluzji analizowany wątek, jakim jest nuda w szkole i jej destrukcyjny wpływ na uczniów i proces ich włączania.

\section{Braki w zakresie kapitału społecznego w systemie edukacji i potrzeba jego (re)animowania w celu skutecznego włączania uczniów z niepełnosprawnością}

W Polsce od wielu lat następuje stopniowa degradacja kapitału społecznego, co skutkuje pogłębianiem się społecznej próżni, której „zasypywanie” jest możliwe poprzez rozwój u obywateli poczucia sprawstwa i znaczenia własnej aktywności. Kapitał społeczny oznacza bowiem rozbudowaną kulturę partycypacji wszystkich obywateli w życiu społecznym, wytworzoną na bazie wiedzy o mechanizmach funkcjonowania demokratycznego społeczeństwa oraz świadomości znaczenia współpracy z innymi dla dobra ogółu [Mikiewicz, Jonasson 2011; por. też Czapiński 2015]. Można także, jak czynią to Piotr Mikiewicz i Jon Torfi Jonasson, wskazać pewną idealną wizję funkcjonowania społeczeństwa obywatelskiego; społeczności bogatej w zasoby kapitału społecznego. Cechuje ją przede wszystkim duża wrażliwość ludzi na problemy społeczne, a zatem również dążenie do usuwania barier we wszystkich sferach życia osób z niepełnosprawnościami, w tym w systemie edukacji. Ponadto, obywatele mają dużą wiedzę na temat działania i zaufanie do instytucji państwowych, regionalnych, lokalnych. Występuje także wyraźna harmonia pomiędzy kapitałem typu wiążącego i pomostowego, zaufanie między ludźmi w codziennym życiu i pracy, dążenie do stowarzyszania się (kultura partycypacji), silny sektor NGO oraz zaangażowanie w lokalne inicjatywy polityczne [Mikiewicz, Jonasson 2011: 161. Słabości we wskazanym zakresie powodują, że aktualnie, w ramach Strategii Rozwoju Kapitału Społecznego 
w Polsce ${ }^{1}$, uruchamiane są działania mające na celu jego wzmocnienie. Wskazuje się w niej na konieczność interwencji państwa, w partnerskim współdziałaniu z obywatelami, w następujących kluczowych obszarach - w kształtowaniu postaw i kompetencji społecznych, współdziałaniu, partycypacji i komunikacji społecznej, kultury i kreatywności.

Rozważając znaczenie dla procesu inkluzji i integracji osób z niepełnosprawnościami wszystkich działań (re)animujących rodzimy kapitał społeczny w wymienionych, jako priorytetowe, obszarach, szczególnie zaakcentuję rolę i wpływ kultury w tym procesie. Odnosząc wpływy czynników kulturowych do przestrzeni włączającej edukacji wypada przede wszystkim wskazać na ich niebagatelne znaczenie dla kreowania pozytywnych zachowań i postaw wobec uczniów z niepełnosprawnościami i ich rodziców/opiekunów, ustanawiania akceptowanych przez całą społeczność szkolną form czy sposobów komunikacji oraz proponowanych organizacyjnych rozwiązań w zakresie ich spersonalizowanego wspierania. To doskonała baza dla rozwoju wzajemnego zaufania, otwartości na relacje, szacunku do siebie i innych, możliwości współpracy, w tym z lokalnym środowiskiem. A ponieważ edukacja jest krytykowana za to, że jest ciągle głównym mechanizmem alokacji ludzi w strukturze społecznej i w związku z tym wiąże się z procesami reprodukcji społecznej, to wpływ kultury w jej przestrzeni przyjmuje jeszcze jedno, istotne znaczenie [Mikiewicz 2011]. Mamy bowiem do czynienia z wyraźnym różnicowaniem ścieżek edukacyjnych dla osób pochodzących z różnych warstw i środowisk społecznych, które nie ma nic wspólnego z koniecznością oferowania wszystkim, a więc pełno- i niepełnosprawnym uczniom zróżnicowanejadekwatnej do potrzeb, możliwości i zainteresowań, oferty wsparcia i kształcenia. Dlatego, jak podkreśla Maria Czerepaniak-Walczak [2015: 82], odnosząc swoje rozważania właśnie do kultury szkoły, niezbędne jest poznanie dynamicznie zmieniających się warunków i sposobów jej funkcjonowania, a zwłaszcza konfiguracji idei, przekonań, poglądów, postaw i relacji oraz pisanych i niepisanych zasad wyznaczających to funkcjonowanie i zachowania wszystkich kreujących jej codzienność podmiotów. Przy tym za równie istotne uznaje rozpoznanie i kształtowanie kultury szkoły ze względu na rodzaj zaufania pomiędzy podmiotami - uczestnikami interakcji edukacyjnych. Dla skuteczności uruchamianych prointegracyjnych czy inkluzyjnych działań i rozwiązań w przestrzeni szkoły bez wątpienia istotne będzie, jaka kultura jest $\mathrm{w}$ niej rozwijana - zaufania paternalistycznego czy krytycznego. Pierwszą „....cechuje zaufanie interpersonalne bazujące na magicznym lub naiwnym zawierzeniu tym, którzy sprawują władzę,

1 Monitor Polski, Dz. Urz. RP, Warszawa, dnia 16 maja 2013 r., poz. 378, Uchwała Nr 61 Rady Ministrów z dnia 26 marca 2013 r. w sprawie przyjęcia "Strategii Rozwoju Kapitału Społecznego 2020" http://prawo.sejm.gov.pl/isap.nsf/download.xsp/WMP20130000378/O/M20130378.pdf [dostęp: 16.10.2018]. 
uznawaniu formalnych symboli oraz praktyk społecznych i edukacyjnych, a także poleganiu na normach ustalanych odgórnie. Przejawia się to w idolatrii oraz uznaniu moralnego i intelektualnego zwierzchnictwa tych, którzy dysponują siłą oraz tworzą ramy doświadczeń uczestników życia szkolnego" [Czerepaniak-Walczak 2015: 82]. Dla dzieci/uczniów z niepełnosprawnościami oznaczać to może konieczność podporządkowania się odgórnie zaprogramowanym, niekonsultowanym i dlatego nieelastycznym regułom pracy w szkole, odejście od indywidualizowania wymagań i uprzedmiotowienie $w$ decydowaniu o formie kształcenia czy wymiarze i zakresie koniecznego bądź oczekiwanego wsparcia. Przejawem takich praktyk była na przykład próba odebrania wielu dzieciom możliwości uczenia się z pełnosprawnymi rówieśnikami poprzez ograniczenie nauczania indywidualnego tylko do zajęć w domu. Ministerstwo Edukacji Narodowej, które opracowało taki projekt rozporządzenia, po protestach rodziców obiecało zmienić zawarte w nim zapisy². Gdyby weszły w życie społeczna ekskluzja dotknęłaby ponad 20 tys. dzieci w Polsce. Tego typu praktyki nie byłyby możliwe $\mathrm{w}$ sytuacji upowszechniania $\mathrm{w}$ systemie edukacji kultury krytycznego zaufania, cechującego się refleksyjnym podejściem do odgórnie ustanawianych regulacji prawnych, zaangażowaniem wszystkich członków szkolnej społeczności w realizowane zadania, mających poczucie sprawstwa i otwartych na kooperację, $w$ tym z lokalnym środowiskiem. Ten typ kultury, jak podkreśla Maria Czerepaniak-Walczak [2015: 82], „(...) funkcjonuje w efekcie negocjowania znaczeń, uzgadniania celów i dróg ich osiągania". Podstawą takiego kształtowania i funkcjonowania zaangażowanej kultury szkoły jest wzajemne zaufanie, które należy (re)animować w przestrzeni polskiej edukacji.

Kapitał społeczny i jego nieodłączny element - zaufanie interpersonalne, może być istotnym zasobem dla budowania pozytywnych relacji między pełnoi niepełnosprawnymi uczestnikami procesu edukacji, eliminowania między nimi uprzedzeń i stereotypów, jak też tworzenia spersonalizowanego, $w$ tym prewencyjnego systemu ich wspierania. Gwarantuje zatem większą skuteczność społecznej inkluzji i integracji uczniów z niepełnosprawnościami, jak też specjalnymi potrzebami, ponieważ buduje lepszą niż dotąd ich pozycję w strukturze społecznej szkoły i lokalnego środowiska. Ta kwestia ma niebagatelne znaczenie dla funkcjonowania szkoły, jako (samo)uczącej się organizacji, a więc pozostającej w silnych

2 Zob. Rodzice protestowali, resort zmienia przepisy. Nauczanie indywidualne nie tylko w domu https://www.tvn24.pl/wiadomosci-z-kraju,3/men-zmienia-przepisy-dotyczace-nauczania-indywidualnego,740194.html [dostęp: 4.10.2018]. Aktualnie dysponujemy już dokumentem, który obwią- zuje i uwzględnia ,autopoprawki ustawodawcy wprowadzone wskutek protestów społecznych: Rozporządzenie Ministra Edukacji Narodowej z dnia 9 sierpnia 2017 r. w sprawie indywidualnego obowiązkowego rocznego przygotowania przedszkolnego dzieci i indywidualnego nauczania dzieci i młodzieży (Dz. U. 2017, poz. 1616), http://prawo.sejm.gov.pl/isap.nsf/download.xsp/ WDU20170001616/O/D20171616.pdf [dostęp: 4.10.2018]. 
relacjach z zewnętrznym środowiskiem, niejako „żyjąc” z nim w symbiozie [por. Senge 2003]. Tym samym tworzy z nim dynamiczną strukturę, inspirującą wszystkie podmioty do wspólpracy, stałej komunikacji, sprzyjającej wymianie doświadczeń w tworzeniu nowych inicjatyw i rozwiązań na rzecz społecznej integracji osób z niepełnosprawnościami. Ulokalnianie działań na rzecz tych osób jest rzeczywistym otwarciem się małych wspólnot na ich potrzeby, możliwości i ograniczenia. Może więc być źródłem społecznych korzyści, a nie, zbyt często, wykluczającej bierności. Reorganizowanie pracy szkoły w duchu kultury krytycznego zaufania stwarza warunki do realizacji nowych, inkluzyjnych przedsięwzięć społecznych. Owe dążenia mogą być także traktowane, jako inwestycja i zarazem narzędzie do poszukiwania nowych rozwiązań w aktywizowaniu zasobów organizacyjnych szkoły i jej środowiska.

\section{Problem ubóstwa uczniów z niepełnosprawnością i potrzeba jego ograniczania w przestrzeni włączającej edukacji}

Ubóstwo jest w naszym kraju ciągle aktualnym, społecznie i politycznie wrażliwym problemem, którego usuwanie czy choćby ograniczanie wymaga zintensyfikowania szeroko zakrojonych, systemowych działań, ale także tych w skali mikro, w społecznościach lokalnych, szkolnych czy wspólnotach rodzinnych. W sytuacji upowszechniania społecznej i edukacyjnej inkluzji osób z niepełnosprawnościami ten problem, który w sposób szczególny te osoby dotyka ${ }^{3}$, obliguje do uruchamiania efektywnych i długofalowych programów pomocowych, sprofilowanych na ich rzeczywistych, zróżnicowanych potrzebach, jak też aktywizacji i usamodzielnianiu. Niezbędna jest zatem mobilizacja "samych biednych" i na tyle ile jest to możliwe „....wzięcie przez nich odpowiedzialności za swój los i swoją biedę" [Kaźmierczak-Kałużna 2012, s. 156]. Nawet najbardziej kompleksowe programy wsparcia czy pomocy nie przyniosą oczekiwanych rezultatów bez aktywnego udziału zainteresowanych, ich osobistego zaangażowania i działań samopomocowych, inicjowanych jednak w sprzyjających warunkach instytucjonalnych, $\mathrm{w}$ tym $\mathrm{w}$ przestrzeni edukacji. Wykorzystywane dotychczas $\mathrm{w}$ walce z ubóstwem instrumenty okazały się niestety niewystarczające, a oficjalnie tworzone projekty naprawcze zbyt rzadko uwzględniają subiektywny wymiar ubóstwa i percepcję własnej sytuacji przez osoby nim dotknięte [Kaźmierczak-Kałużna 2012]. Uwzględnienie roli i znaczenia osób z niepełnosprawnością w procesie wy-

3 Raport o biedzie, Szlachetna Paczka 2017, https://szp.azureedge.net/Web/upload/raport2017/raport_o_biedzie_2017_v2.pdf [dostęp: 20.09.2018]. Szlachetna Paczka 2018, Raport o biedzie, https://szp.azureedge.net/upload/bieda2018/szlachetna-paczka-raport-o-biedzie-2018.pdf [ dostęp: 20.09.2018]. 
chodzenia z ubóstwa, nie zwalnia służb pomocowych i innych profesjonalistów, a w szczególności kadry pedagogicznej (wszystkich rodzajów szkół) z wrażliwości i umiejętności dostrzegania jego różnych form i swoistych masek u oczekujących wsparcia wychowanków i ich rodzin [por. Tarkowska 2012]. Wielość postaci ubóstwa, którego konsekwencją nierzadko jest wykluczenie i marginalizacja dziecka w społeczności uczniowskiej, wskazuje na potrzebę nie redukowania tego problemu tylko do kwestii materialnych czy finansowych. Ubóstwo, jak podkreśla Maria Jarosz [2002: 268], „(...) dotyka ludzi, których sytuacja wskazuje na niezaspokojenie większości podstawowych potrzeb życiowych (jedzenie, ubranie, mieszkanie, zdrowie, bezpieczeństwo), ale też potrzeb ponadpodstawowych (kultura, oświata, wypoczynek)".

Bariery edukacyjne - społeczne, kulturowe i psychologiczne, jakie w ocenie Elżbiety Tarkowskiej [2012] piętrzą się przed dzieckiem ze środowiska biedy, to m.in. wyniesiony z domu brak aspiracji edukacyjnych, środowiskowe wzory drogi zawodowej, w której nie ma miejsca na naukę i w nie mniejszym stopniu problemy z poczuciem własnej wartości czy zaniżoną samooceną własnych cech i możliwości. Równie dotkliwe są bariery ekonomiczne ${ }^{4}$, kiedy standardowe wydatki związane ze szkołą przekraczają możliwości finansowe rodziców i w związku z tym także pozalekcyjna czy rekreacyjna oferta szkolna staje się dla ich dzieci niedostępna. Brak zrozumienia ze strony nauczycieli i rówieśników, narażanie się na wstyd i upokorzenia związane z różnymi brakami, nierzadko zwielokrotniane niepełnosprawnością, zniechęcają do szkoły i skutkują przerwaniem edukacji bądź jej zakończeniem na niskim etapie. Dzieci/uczniowie z rodzin ubogich, o słabym kapitale kulturowym, ze środowisk zaniedbanych i zmarginalizowanych, pozbawione wychowania i wsparcia najbliższych, zbyt często nie znajdują go również w szkole, która przecież powinna stanowić dla nich równie ważną instytucję socjalizacyjną, tym bardziej, że w tak trudnej sytuacji staje się tą jedyną. Kompensująca rola szkoły w tym zakresie nie powinna się jednak sprowadzać do działań doraźnych czy incydentalnych lecz długofalowych, perspektywicznych, zorientowanych na rozwój i edukację dziecka [Tarkowska 2011], a jeśli to niezbędne też wsparcie w procesie rehabilitacji i inkluzji społecznej w szkolnym, rodzin-

$\overline{4} \mathrm{~W}$ tym miejscu wypada zaznaczyć, że ubóstwo w różnym stopniu dotyka poszczególne grupy osób, jednak społeczna mapa zagrożenia tym problemem w naszym kraju nie zmienia się istotnie od lat. Jedną z grup zagrożonych są gospodarstwa z osobami z niepełnosprawnością - ok. 7\% (dla porównania zagrożenie ubóstwem gospodarstw domowych bez osób z niepełnosprawnością jest znacznie niższe i wynosi - 4,7\%). Przy tym zasięg ubóstwa skrajnego w latach 2016-2017, ustalanego w badaniach według obecności osób z orzeczeniem o niepełnosprawności w gospodarstwie domowym, zmniejszył się. Wyraźną poprawę zauważono w sytuacji gospodarstw domowych z przynajmniej 1 dzieckiem do lat 16 posiadającym orzeczenie o niepełnosprawności - z 8,3\% w 2016 r. do 4,9\% w 2017 r. Natomiast w sytuacji, gdy głową gospodarstwa domowego jest osoba z niepełnosprawnością, zmiana jest niewielka - z 6,6\% w 2016 r. do 6,3\% w 2017 r. [Zasięg ubóstwa ekonomicznego w Polsce, GUS 2018]. 
nym i lokalnym środowisku. Konieczne są zatem takie proinkluzyjne działania, które z założenia będą eliminować dyskryminację uczniów z rodzin ubogich, a zatem uwzględniać fakt, że ich „....nierówne traktowanie może pojawiać się w kontekście systemowego funkcjonowania szkół (wsparcie socjalne uczniów, w tym jego dostępność, forma i jakość), stylów zarządzania placówkami oraz tworzenia atmosfery w szkole (włączające lub wyłączające dzieci z rodzin ubogich), kontaktów między szkołą a rodzinami dotkniętymi ubóstwem (wsparcie lub jego brak), podejścia nauczycieli (od działania na rzecz dzieci ubogich poprzez ignorowanie różnic po defaworyzowanie) oraz kontaktów rówieśniczych - między dziećmi z rodzin zamożnych i biednych (wielorakie strategie współpracy, marginalizacja, przemoc ?zyczna lub symboliczna)" [Gawlicz, Rudnicki, Starnawski 2015: 27].

Na podobne kwestie, jako przyczyny nieradzenia sobie szkoły z ubóstwem uczniów, wskazywała już dekadę temu Elżbieta Tarkowska [2008] podkreślając, że powodem jest przesadna koncentracja na pracy dydaktycznej, brak odpowiednio przygotowanej kadry, trudności w zidentyfikowaniu problemu ubóstwa uczniów, nierzadkie przypadki jego bagatelizowania lub umniejszania czy przenoszenia odpowiedzialności na inne instytucje. Słabością jest także niesatysfakcjonująca uczniów współpraca szkoły z ich rodzicami, lokalnym środowiskiem, a w szczególności z tymi funkcjonującymi w nim podmiotami, które mogłyby okazać wsparcie $w$ jego rozwiązywaniu czy choćby ograniczaniu. Tymczasem ubóstwo dla zbyt wielu dzieci w Polsce oznacza odtwarzanie realiów życia ich rodzin i społeczności, praktycznie bez możliwości zmiany swojego statusu. Taka sytuacja, zwielokrotniona niepełnosprawnością, utrudnia dzieciom uczestnictwo w społeczeństwie, kulturze i procesie dalszego kształcenia [Gawlicz, Rudnicki, Starnawski 2015]. Obliguje zatem pedagogów i nauczycieli, we współpracy z ich rodzinami i najbliższym środowiskiem, do wypracowania nowej formuły funkcjonowania szkoły w celu eliminowania napięć, kon?iktów czy przejawów ich deprecjonowania i wykluczania z uczniowskiej i lokalnej społeczności. Właściwe zarządzanie placówką i umiejętne wykorzystanie kompetencji nauczycieli i innych specjalistów, a w szczególności pedagoga szkolnego i pedagogów specjalnych oraz poszerzanie opieki nad dziećmi poza szkołą może ułatwić proces ich inkluzji i wychodzenia z ubóstwa.

\section{Nuda w szkole i jej destrukcyjny wpływ na uczniów z niepełnosprawnością i proces ich włączania}

W rozważania dotykające kwestii ubóstwa kapitału społecznego i pochodzenia z rodziny ubogiej oraz konsekwencji ich doświadczania przez uczniów z niepełnosprawnościami, włączanych w system ogólnodostępnej edukacji, wpisuje 
się także problem nudy - element ukrytego programu szkoły, równie destrukcyjny dla ich relacji społecznych i osiągnięć w nauce. Nuda w kontekście edukacyjnym może być wiązana $z$ takimi niekorzystnymi zjawiskami, jak niezadowolenie i wrogość wobec szkoły, lekceważenie obowiązujących w niej reguł i zasad komunikacji, trudności z przetwarzaniem informacji, niski poziom uwagi, mniejsza motywacja do pracy i w konsekwencji niezadowalające efekty w nauce. Może także powodować unikanie, a nawet porzucenie szkoły, zażywanie substancji psychoaktywnych, dewiacyjne zachowania i przestępczość [Finkielsztein 2016]. Rosnące problemy dydaktyczne i wychowawcze uczniów czynią nudę negatywną, destrukcyjną emocją, której doświadczają w toku pracy w szkole, mimo pełnego zagospodarowania ich czasu, wypełnionego nierzadko bogatą ofertą zróżnicowanych, także pozalekcyjnych i pozaszkolnych zajęć. W kontekście wskazanych słabości, już dwie dekady temu Zbigniew Kwieciński [1995; por. też 2002, 2012] postrzegał szkołę, jako zorganizowaną stratę czasu i postulował, aby poddać pogłębionej analizie jego wykorzystanie na lekcji przez nauczycieli i uczniów. Za równie istotne uznawał właściwe gospodarowanie czasem spędzanym w szkole przez uczniów w związku z przedłużającym się w niej ich pobytem w ciągu dnia, jaki w ciągu życia. Chodzi o to, aby nie stała się ona także zorganizowaną blokadą ich rozwoju.

Swoistą aktualizację wyników badań i refleksji Zbigniewa Kwiecińskiego dostrzegam w wynikach badań Piotra Stańczyka [2012], który podkreśla, że nuda jest znaczącym elementem doświadczenia szkoły; stanowi więc element definiujący to, czego uczniowie doświadczają jako pracy w szkole. I dodaje, że właśnie jako wątek określający doświadczenie szkoły, nuda pojawia się nieproszona w odpowiedziach na pytania o sens szkoły, pracy i samookreśleń tożsamości badanych uczniów i nauczycieli. Na przykład w nauczycielskiej koncepcji sensu pracy „....nuda pojawia się jako „rodzący się problem”, który ma swe przyczyny w „uprzedzeniu do informacji” jako „informacji nieprzydatnej”, bo „niewiążącej się z przyszłością", ale także w takim „uprzedzeniu”, które bierze się z „narzucenia" - „to co jest narzucone, to nie jest lubiane”. Wobec czego szkoła, jak kontynuuje autor, „... wsparta na fundamencie obowiązku szkolnego, (...) obsesyjnie przywiązana do dyscypliny jest z konieczności nudna - taka nieuświadamiana konsekwencja może zostać wyprowadzona z nauczycielskiego pojmowania szkoły" [Stańczyk 2012: 38]. Nauczyciele będą zatem skłonni do postrzegania problemu nudy w kategoriach uczniów z tym problemem [Stańczyk 2012]. Ich niepełnosprawność może być oceniana przede wszystkim przez pryzmat braków, deficytów i ograniczeń, a nie możliwości czy mocnych stron. 


\section{Refleksje końcowe}

Edukacja inkluzyjna osób z niepełnosprawnością i o specjalnych potrzebach w systemie ogólnodostępnego szkolnictwa jest ciągle dużym wyzwaniem dla wszystkich podmiotów, angażujących się w różnym stopniu w jej realizację. Dlatego obliguje te podmioty, a w szczególności zróżnicowaną specjalnościowo kadrę pedagogiczną, do wzajemnej współpracy i wymiany doświadczeń z lokalnym środowiskiem - przedstawicielami władz samorządowych, instytucji, stowarzyszeń itp. Jej celem będzie budowanie wspólnego kapitału społecznego, kreującego przestrzeń do satysfakcjonującego, a więc adekwatnego do możliwości, potrzeb i ograniczeń, włączania tych osób w relacje i więzi społeczne oraz inicjatyw i działań urealniających ich uczestnictwo w i na rzecz tego środowiska. Za wskazane wypada zatem uznać (re)animowanie w szkole i jej środowisku (we współpracy z rodzinami uczniów) przede wszystkim form aktywności o charakterze pomostowym (bridging), wspartych na normach zaufania i wzajemności. Gwarantują one rzeczywistą, nie pozorowaną społeczną partycypację tych osób, bowiem powiązania pomostowe, jak podkreśla Jarosław Działek [2011], mimo, że są luźniejsze, dostarczają zasobów, których brakuje w zamkniętych grupach. Dodatkowymi zaletami gęstej sieci tych powiązań, jak mniemam, będzie lepsza koordynacja podejmowanych przedsięwzięć w celu zacierania dystansu i uprzedzeń między osobami pełno- i niepełnosprawnymi oraz eliminowania czy choćby ograniczania ciągle dotkliwie doświadczanych przez nich stereotypów, ograniczeń i barier. Jednak życie osób z niepełnosprawnościami, w poczuciu wewnętrznego bezpieczeństwa i przynależności społecznej, wymaga także eliminowania innych słabości, które te wartości ograniczają - społecznie drażliwego problemu ubóstwa dzieci i destrukcyjnego wpływu nudy w szkole, jako zwielokratniających ich niepełnosprawność i utrudniających proces inkluzji.

\section{Bibliografia}

Czapiński J. (2015), Stan społeczeństwa obywatelskiego [w:] Diagnoza Społeczna. Warunki i jakość życia Polaków. Raport, J. Czapiński, T. Panek (red.), Rada Monitoringu Społecznego, Warszawa, s. 332-372.

Czerepaniak-Walczak M. (2015), Kultura szkoły - o jej złożoności i wielowymiarowości, „Pedagogika Społeczna", nr 3(57), s. 77-87.

Działek J. (2011), Kapitał społeczny - ujęcia teoretyczne i praktyka badawcza, „Studia Regionalne i Lokalne", nr 3 (45), s. 100-118.

Finkielsztein M. (2016), Istotność nudy w szkole: interdyscyplinarny przeglad badań [w:] Edukacja w zglobalizowanym świecie, V. Tanaś, W. Welskop (red.), Wydawnictwo Naukowe Wyższej Szkoły Biznesu i Nauk o Zdrowiu, Łódź. 
Gawlicz K., Rudnicki P., Starnawski M. (2015), Dyskryminacja w edukacji-przegląd wybranych polskich badań [w:] Dyskryminacja w szkole-obecność nieusprawiedliwiona. O budowaniu edukacji antydyskryminacyjnej w systemie edukacji formalnej w Polsce. Raport z badan, K. Gawlicz, P. Rudnicki, M. Starnawski (red.), Towarzystwo Edukacji Antydyskryminacyjnej, Warszawa.

Janiszewska-Nieścioruk Z., Grzegorzewska I., Herberger J. i in. (2015), Człowiek wobec wyzwań i zagrożeń wspótczesności. Rozwój- rodzina-edukacja, Oficyna Wydawnicza Uniwersytetu Zielonogórskiego, Zielona Góra.

Jarosz M. (2002), Ubóstwo [w:] Encyklopedia socjologii, t. 4, Oficyna Naukowa, Warszawa.

Kaźmierczak-Kałużna I. (2012), Ubóstwo jako problem społeczny. Kwestie terminologiczne i ustalenia empiryczne, „Kultura i Społeczeństwo”, nr 1, s. 147-157.

Kwieciński Z. (1995), Praca w szkole jako złudzenie (studium przypadku) [w:] Socjopatologia edukacji, Z. Kwieciński (red.), wyd. 2 popr. MWN, Olecko.

Kwieciński Z. (2002), Wykluczanie, Wydawnictwo UMK, Torun.

Kwieciński Z. (2012), Edukacja jako blokada rozwoju. Hipotezy dysfunkcjonalności po 20 latach, „Nauka", nr 4, s. 77-85.

Mikiewicz P. (2011), Zmiany we wspótczesnym systemie edukacyjnym w Polsce [w:] Kapitat społeczny i edukacja. Badanie porównawcze pomiędzy Polską i Islandia. Raport podsumowujący, P. Mikiewicz (red.), DSW, Wrocław.

Mikiewicz P., Jonasson J.T. (2011), Czy możliwa jest polityka kapitału społecznego poprzez edukację? [w:] Kapitat społeczny i edukacja. Badanie porównawcze pomiędzy Polską i Islandia. Raport podsumowujacy, P. Mikiewicz (red.), DSW, Wrocław.

Monitor Polski, Dz. Urz. RP, Warszawa, dnia 16 maja 2013 r., poz. 378, Uchwała Nr 61 Rady Ministrów z dnia 26 marca 2013 r. w sprawie przyjęcia "Strategii Rozwoju Kapitału Społecznego 2020" http://prawo.sejm.gov.pl/isap.nsf/download.xsp/WMP20130000378/ O/M20130378.pdf [dostęp: 16.10.2018].

Raport o biedzie, Szlachetna Paczka 2017, https://szp.azureedge.net/Web/upload/raport 2017/raport_o_biedzie_2017_v2.pdf [dostęp: 20.09.2018].

Rodzice protestowali, resort zmienia przepisy. Nauczanie indywidualne nie tylko w domu https://www.tvn24.pl/wiadomosci-z-kraju,3/men-zmienia-przepisy-dotyczace-nauczania-indywidualnego,740194.html [dostęp: 4.10.2018].

Rozporządzenie Ministra Edukacji Narodowej z dnia 9 sierpnia 2017 r. w sprawie indywidualnego obowiązkowego rocznego przygotowania przedszkolnego dzieci i indywidualnego nauczania dzieci i młodzieży (Dz. U. 2017 poz. 1616), http://prawo.sejm.gov. pl/isap.nsf/download.xsp/WDU20170001616/O/D20171616.pdf [dostęp: 4.10.2018].

Sadowska S. (2005), Ku edukacji zorientowanej na zmianę społecznego obrazu osób niepetnosprawnych, Wydawnictwo Edukacyjne AKAPIT, Toruń.

Senge P. (2003), Piąta dyscyplina. Teoria i praktyka organizacji uczących się, tłum. H. Korolewska-Mróz, Oficyna Ekonomiczna, Kraków.

Stańczyk P. (2012), Nuda w szkole - między alienacją a emancypacją, „Teraźniejszość - Człowiek - Edukacja", nr 3(59), s. 35-56.

Szlachetna Paczka 2018, Raport o biedzie, https://szp.azureedge.net/upload/bieda2018/ szlachetna-paczka-raport-o-biedzie-2018.pdf [dostęp: 20.09.2018]. 
Tarkowska E. (2008), „Nie masz kasy. Jesteś nikim”. O pogłębianiu nierówności przez szkołę [w:] Wychowanie. Pojęcia, procesy, konteksty, M. Dudzikowa, M. Czerepaniak-Walczak (red.), t. 4, Gdańskie Wydawnictwo Psychologiczne, Gdańsk

Tarkowska E. (2011), Ubóstwo dzieci w Polsce [w:] Ubóstwo i wykluczenie społeczne w Polsce. Raport krajowy Polskiej Koalicji Social Watch i Polskiego Komitetu European Anti-Powerty Network, R. Szarffenberg (red.), Kampania Przeciw Homofobii, Warszawa.

Tarkowska E. (2012) „Dałem głos ubogim...”. Ryszard Kapuściński o ubóstwie i ludziach ubogich, „Kultura i Społeczeństwo”, nr 1, s. 37-50. 